\title{
Status and distribution of the endemic Bali starling Leucopsar rothschildi
}

\author{
S. (Bas) van Balen, I Wayan A. Dirgayusa, I Made W. Adi Putra and Herbert H. T. Prins
}

\begin{abstract}
The Bali starling Leucopsar rothschildi is a passerine endemic to the dry monsoon forest of the island of Bali, Indonesia. Habitat conversion and excessive capture for the pet trade brought the species to the verge of extinction in the 1980s. The species is critically endangered because of 1) an extremely small population size, 2) restriction to a small area, 3) illegal trapping,
\end{abstract}

and 4) diminishing suitable habitat left within its natural range. An intricate web of factors prevents the Bali starling from emerging from this precarious situation.

Keywords Bali Island, Bali starling, conservation, endangered species, Indonesia, Leucopsar rothschildi, status.

\section{Introduction}

The Bali starling (Bali or Rothschild's mynah) Leucopsar rothschildi represents a monotypic genus, which is endemic to the island of Bali (Indonesia). Habitat destruction and capturing for the pet trade brought the species to the verge of extinction. In 1990 and, after a temporary recovery, in 1998 the species was at an all-time-low number of fewer than 15 individuals, restricted to the Bali Barat National Park (van Balen \& Gepak, 1994; I. Z. Mutaqin, pers. comm., 1998).

On account of its restricted range, its extremely small numbers in the wild and pressures on the last freeranging birds, the Bali starling is considered critically endangered according to the newest International Union for Conservation of Nature (IUCN) threat categories (Collar et al., 1994). In this paper we present a reconstruction of the species's historical distribution and decline. We also report current population trends and evaluate the possible factors that induced the population crash and those that are likely to inhibit recovery of the population.

\section{S. (Bas) van Balen (corresponding author) BirdLife International-Indonesia Programme, P.O. Box 310, Bogor 16003, Indonesia. Present address: Wageningen University, Tropical Nature Conservation and Vertebrate Ecology Group, Bornsesteeg 69, 6708 PD, Wageningen, the Netherlands. Tel.: +31317 483 596; fax: + 31317484 845; e-mail: Bas.vanBalen@staf.ton.wag-ur.nl}

I Wayan A. Dirgayusa and I Made W. Adi Putra Yayasan Konservasi Alam Nusantara, Jalan Pamekar Raya 10, Bandung 40613, Indonesia. Tel. fax: +62 22780 0780; e-mail: konus@bdg.centrin.net.id

Herbert H. T. Prins Wageningen University, Tropical Nature Conservation and Vertebrate Ecology Group, Bornsesteeg 69, 6708 PD, Wageningen, the Netherlands. Tel.: + 31317483900 ; fax: + 31317484 845; e-mail: Herbert.Prins@staf.ton.wag-ur.nl; Web: www.slm.wau.nl/natcons/ND

Revised manuscript accepted for publication 7 March 2000

\section{Methods}

Literature study

A number of reports on Bali starling distribution were consulted (see van Balen, 1995a). Figures obtained between 1974 and 1984 on the population size of the Bali starlings were interpreted with caution, because they refer to partial inventories, i.e. counts of only a restricted number of roosts. For the reassessment of the population estimates between 1974 and 1984, the intensity of surveying, coverage, dispersal behaviour of the Bali starling and contemporary weather conditions were taken into account.

\section{Population censuses}

In 1984, the Indonesian Department of Forest Protection and Nature Conservation (PHPA), in co-operation with BirdLife International (then ICBP), started monitoring the wild population on a regular basis. The census method was standardized (van Balen, 1995b), based on a counting method already in use by the Bali Barat reserve managers (I M. S. Adi, pers. comm.). Until 1991, one annual census of the wild population was made at the end of the dry monsoon (September-October), when the birds associate in roosting flocks. During the recovery of the wild population a second annual postbreeding census was introduced immediately after the last young birds had fledged (May or June) and coinciding with the first weeks of the dry monsoon. This provided data on population dynamics, in particular the relationship between fledging success and population size. Each census extended over a period of 4 days. Dusk and dawn counts lasting $2.5 \mathrm{~h}$ each were made by $9-18$ teams of two to three experienced park wardens. Each team was posted at a strategic position near roosting sites, or along flight routes to and from 
these sites. These sites were identified during reconnaissance visits 1 or 2 weeks prior to each census. Numbers of in-going and out-going birds and passersby, flight direction, times of observation and weather conditions, were recorded on standard forms. To monitor dispersion and range expansion, which might occur with increasing population size, we conducted surveys outside the known current range. These concentrated along the north and south coast of west Bali and preceded the pre-breeding census when the birds were maximally dispersed.

\section{Interviews}

M. W. Adi Putra conducted semi-structured interviews with local people living within the historical range of the Bali starling. Fifty respondents aged 25 years and older were questioned about the occurrence, numbers and time of extirpation of Bali starlings in their area. Additional information was requested about habitat, seasonality in distribution and roosting sites.

\section{Historical synopsis}

\section{Pre-1935: early distribution and numbers}

Stresemann $(1912,1913)$ collected the first Bali starling known to science near Bubunan, from where its range ran in a westerly direction (Fig. 1). Its habitat was described as 'dry savannah and shrub woodlands', and 'tall and dense forest' in the 1920s (van der Paardt, 1926; von Plessen, 1926), historically restricted to a narrow belt with a dry monsoon climate (Walker et al., 1980). Monsoon forests exist where there are several dry months (each with $<60 \mathrm{~mm}$ rainfall) annually. They are mostly deciduous, although perhaps only briefly, have fewer climbers and epiphytes, and are less

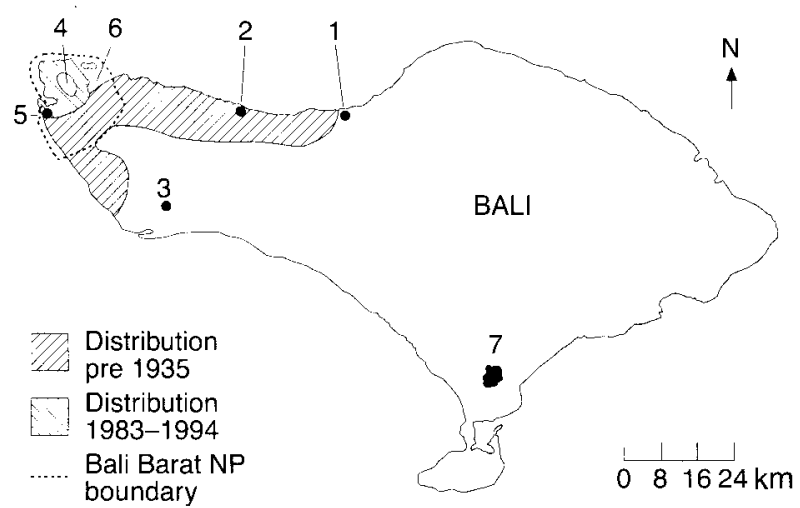

Fig. 1 Distribution of Bali starlings, 1911-98. (1: Bubunan; 2: Gerokgak; 3: Negara; 4: Prapat Agung Peninsula; 5: Gilimanuk; 6: Teluk Terima; 7: Denpasar). species rich (Whitmore, 1990). At the beginning of the 20th century this forest type was largely undisturbed in the unpopulated north-western part of Bali, and only sporadically interspersed with alang-alang Imperata cylindrica fields, in particular along the north coast (von Plessen, 1926). In the 1920s, the Dutch colonial government leased out 600 ha for kapok Ceiba pentandra and coconut Cocos nucifera in the Teluk Terima area, in the centre of Bali starling distribution and now national park territory.

Reports from 1914 to 1926 mention the low densities of Bali starlings in the northern coastal areas of western Bali in February-July, but large numbers in September-November, towards the end of the dry monsoon, throughout north-western Bali, including Gilimanuk on the west coast. Hundreds of Bali starlings visiting an abandoned papaw Carica papaya plantation in the Teluk Terima area (von Plessen, 1926), and flocks of 30 and more birds were seen throughout the entire north-west of Bali in October-November. They foraged solely on fruiting shrubs of Lantana camara (van der Paardt, 1926) which, ironically, is a naturalized invasive plant from tropical America (Backer \& Bakhuizen van den Brink, 1965). Bali starlings occurred in small numbers in the higher parts of the hills in the interior of west Bali (von Plessen, 1926). The north coast of west Bali was the centre of the species's distribution, and numbers declined sharply in easterly and southerly directions. Although he travelled extensively throughout the rest of Bali, von Plessen (1926) failed to see the species anywhere else. These observations were confirmed by reports from local people.

West \& Pugh (1986) gave a rough population estimate of 300-900 birds for wild Bali starling at the time of its discovery. They based this number on the reduction of the species's range, assuming a density similar to those reported over the last decade. Although the Bali starling appears to have always been scarce, this estimate is likely to be far below the real numbers, considering the starling's range, which was larger than was thought before, and the huge numbers of birds that were captured and exported between the 1960s and 1980s (see Table 1).

\section{0-74: the 'exodus'}

Forests on Bali and Java continued to shrink rapidly during this period (Smiet, 1992; Whitten et al., 1996) and human settlements started to appear in the Bali starling's range. In 1947, the 19,366 ha Bali Barat game reserve was established, theoretically securing a large part of the species's range. However, the Margasari social forestry project was established in 1970 within the game reserve. No information is available from the 
Table 1 Selected events in the history of Bali starling Leucopsar rothsschildi trade

\begin{tabular}{|c|c|}
\hline 1928 & $\begin{array}{l}\text { First five Bali starlings exported to Europe. } \\
\text { Three years later they bred in captivity (Ezra, } \\
\text { 1931). }\end{array}$ \\
\hline $1960-62$ & $\begin{array}{l}\text { Large imports appeared in Europe: a single } \\
\text { assignment of } 50 \text { birds reported from UK } \\
\text { (Harrison, 1968). }\end{array}$ \\
\hline \multirow[t]{2}{*}{1969} & $\begin{array}{l}\text { Birds found in } 11 \text { countries throughout the } \\
\text { world, e.g., Belgium, Hong Kong, Sri Lanka, } \\
\text { USA (Spilsbury, 1970). }\end{array}$ \\
\hline & $\begin{array}{l}\text { Official reports of } 55 \text { birds refused entry to the } \\
\text { USA, and another shipment entering the USA } \\
\text { despite the banned importation after the } \\
\text { Endangered Species Act in the same year } \\
\text { (King, 1974). }\end{array}$ \\
\hline Early $1970 \mathrm{~s}$ & $\begin{array}{l}\text { Hundreds of birds transported into Europe, the } \\
\text { majority in hands of malevolent aviculturists } \\
\text { (Morrison, 1981). Illegal railway transport } \\
\text { of } 200 \text { Bali starlings confiscated in Jakarta } \\
\text { (K. Oesman, pers. comm., 1994). }\end{array}$ \\
\hline 1972 & $\begin{array}{l}\text { Thirty birds counted in Singapore bird park } \\
\text { (Morrison, 1981). }\end{array}$ \\
\hline 1976 & $\begin{array}{l}\text { Fifteen birds in Surabaya bird market for export } \\
\text { to Singapore through Jakarta (Suwelo, 1976). }\end{array}$ \\
\hline 1979 & $\begin{array}{l}\text { Nine birds seen in Singapore bird park; never } \\
\text { less than } 19 \text { encountered in the local shops } \\
\text { for sale (Morrison, 1981). }\end{array}$ \\
\hline 1982 & $\begin{array}{l}\text { Sixteen seen together in cages in Denpasar, the } \\
\text { property of one man; trappers seen active } \\
\text { in one of the main roosts in Bali Barat } \\
\text { (Ash, 1984). }\end{array}$ \\
\hline
\end{tabular}

wild in this period, which is characterized by a general lack of ornithological activities throughout the Indonesian archipelago (Junge, 1953; Jepson, 1997). The trade in wild Bali starlings reached its height in the early 1960s and 1970s when hundreds of birds were exported overseas (van Bemmel, 1974; Seibels \& Bell, 1993). Table 1 lists a number of important events in the Bali starling trade (undoubtedly the 'tip of the iceberg'). Many Bali starlings were exported even after the spe- cies was put on Appendix 1 of the Convention on International Trade in Endangered Species (CITES) in 1970 , and received protected status under Indonesian law in 1971.

\section{4-83: the decline}

Accounts of local people indicate that the conversion of monsoon forest to agricultural land had a negative impact on Bali starlings. Nevertheless, there are reports of Bali starlings occurring in man-made environments and even of Bali starlings breeding in coconut groves (J. R. Hayward, A. J. Ringrose, J. D. Lee \& W. J. D. Magill, Oxford Expedition, 1980, unpublished data). Bali Barat received national park status in 1982.

Fifty years after its discovery, the first information on Bali starling numbers became available. Time and budget constraints resulted in estimates that are extrapolations from censuses of known roosts rather than comprehensive censuses. Population estimates were made almost annually and Tables 2 and 3 give population estimates between 1974 and 1983. It should be noted that spring counts were most likely boosted by fledglings, whereas the autumn counts were taken after the dry season, when most of the annual mortality had occurred.

Interestingly, Bali starlings were found in fair numbers at places (notably Manistutu) where von Plessen (1926) failed to observe any. The figures also show that on the periphery of distribution, where most of the poaching took place, numbers shrunk rapidly. Interviews with local people made clear that in the 1960s the Bali starling largely disappeared from the southern part of its range and in the 1970s from the north-east.

\section{3-94: Bali Starling Project}

From 1983 to 1994, the species has been the subject of a conservation programme, called the Bali Starling Pro-

Table 2 Population estimates of the wild Bali starlings, 1974-83

\begin{tabular}{lllcll}
\hline & & \multicolumn{2}{l}{ Population estimate } & \\
\cline { 3 - 5 } Year & Month & Pre & Breeding & Post & Sources \\
\hline 1974 & October & 100 & - & - & Sungkawa et al., 1974 \\
1975 & February & - & - & $68-144$ & Natawiria, 1975 \\
1976 & September & $175(+25)$ & - & - & Suwelo, 1976 \\
& December/January & - & $>127$ & - & Sieber, 1978 \\
1977 & August/September & 110 & - & - & Alikodra et al., 1978 \\
1979 & March/April & - & - & $150-200$ & de Iongh et al., 1979 \\
1980 & August & $207(+22)$ & - & - & Hayward et al. (Oxford Expedition), unpublished data \\
1981 & October & 254 & - & - & I M. Sutaadi (BBNP), unpublished data \\
1983 & October & 142 & - & - & J. Rustandi (PPA Denpasar), unpublished data \\
\hline
\end{tabular}


Table 3 Distribution and numbers of Bali starling across west Bali, 1974-80

\begin{tabular}{|c|c|c|c|c|c|c|c|}
\hline \multirow[b]{2}{*}{ Month } & \multicolumn{7}{|l|}{ Year } \\
\hline & $\begin{array}{l}1974^{*} \\
\text { October }\end{array}$ & $\begin{array}{l}1975 t \\
\text { February }\end{array}$ & $\begin{array}{l}1976 \ddagger \\
\text { September }\end{array}$ & $\begin{array}{l}\text { 1977§ } \\
\text { January }\end{array}$ & $\begin{array}{l}\text { 1979đI } \\
\text { March/April }\end{array}$ & $\begin{array}{l}1979^{* *} \\
\text { August }\end{array}$ & $\begin{array}{l}\text { 1980t+ } \\
\text { August }\end{array}$ \\
\hline 1. Cekik & - & - & - & - & 2 & 2 & 2 \\
\hline 2. Sumber Batok/Klampok & 40 & 40 & - & $x$ & 4 & - & - \\
\hline 3. Tegal Bunder/Sawo Kecik & 2 & 20 & 35 & $x$ & - & 5 & 10 \\
\hline 4. Teluk Lumpur & - & - & - & - & - & 36 & 25 \\
\hline 5. Prapat Agung & 2 & 18 & 0 & $x$ & 25 & 39 & 43 \\
\hline 6. Batu Licin & - & - & - & - & - & - & - \\
\hline 7. Lampu Merah & 13 & 13 & - & $x$ & 26 & 7 & 16 \\
\hline 8. Teluk Kelor & 42 & - & - & $\mathrm{x}$ & 9 & 26 & 41 \\
\hline 9. Batu Gondang & (32) & 36 & 21 & $x$ & 11 & 11 & 10 \\
\hline 10. Teluk Brumbun & - & 12 & - & - & - & 12 & 6 \\
\hline 11. Tanjung Kotal & - & - & - & - & - & 2 & 21 \\
\hline 12. Tanjung Gelap & - & 9 & - & - & - & - & - \\
\hline 13. Teluk Terima & 6 & 7 & 10 & $x$ & - & 7 & 6 \\
\hline 14. Banyuwedang & 13 & 15 & 82 & $x$ & 7 & 18 & 19 \\
\hline 15. Krapeyak & - & - & - & - & - & 2 & - \\
\hline 16. Sumber Batok & - & - & - & $x$ & - & 5 & 8 \\
\hline 17. Sumberrejo & - & - & 5 & - & - & - & - \\
\hline 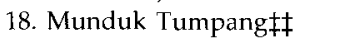 & - & - & - & - & - & - & - \\
\hline 19. Pulakiłł & - & 5 & - & - & - & 7 & - \\
\hline 20. Grokgak㧊 & - & - & - & - & - & 2 & 11 \\
\hline 21. Tegalunan拉 & - & - & - & - & - & 2 & - \\
\hline 22. Yeh Embangł‡ & - & - & - & - & - & 5 & 9 \\
\hline 23. Penyaringanł‡ & - & - & - & - & - & 28 & 22 \\
\hline 24. Manistutułf & - & - & 25 & - & - & - & - \\
\hline Estimated totals & 100 & 100 & 200 & 125 & 110 & 175 & 200 \\
\hline
\end{tabular}

Sources: * Sungkawa et al., 1974; + Natawiria, 1975; † Suwelo, 1976; § Sieber, 1978; II de Iongh et al., 1979, 1982; ** Hayward et al., Oxford Expedition, 1980, unpublished data; †+ van Helvoort et al., 1985.

‡† Outside Bali Barat National Park; $\times$ no figures available.

ject (BSP). Its range shrunk to the fire-induced open shrub and savannah woodland, found below an elevation of $150-175 \mathrm{~m}$ in the north-east part of peninsular Prapat Agung. The open woodlands were dominated by Acacia leucophloea trees with an undergrowth of Lantana camara and Eupatorium shrubs, and Imperata cylindrica grass, and intersected by moister and more densely forested valleys with dominant trees Grewia koordesians, Vitex pubescens, Borassus spp. and Schoutenia spp. This vegetation type might, however, be suboptimal habitat for the Bali starling and it may have been driven there by poaching pressure. Movements between roosting and foraging sites increased towards the end of the dry season when food resources ran short. Some birds dispersed in groups of 20-30 for distances up to $5-6 \mathrm{~km}$ into the open mixed forest edge and flooded savannah woodland in the southern parts of the Prapat Agung Peninsula. Breeding (December-April) was restricted to an area of 500 ha and nest sites were in trees in the valleys described above. Non-breeding and immature birds also roosted in this area, but covered larger distances (up to $2-3 \mathrm{~km}$ ) to forage. Table 4 presents the results of 12 censuses conducted in 1984-94. Each of these was based on six counts on consecutive days. The original estimates of totals have been revised by taking into account possible movements between roosts, and double counts. The censuses show that Bali starlings have disappeared from areas where they occurred only 10 years before.

After a crash of the Bali starling population that started in the early 1980 s and which almost completed the extinction of the species in the wild, the population recovered slightly in 1991-92. This was due mainly to improved and effective protection of the park, in addition to favourable weather conditions, which greatly enhanced breeding success (van Balen \& Gepak, 1994). Figure 2 shows numbers of the wild population and numbers of birds that fledged. After 1992 breeding was good, but did not result in an increase of the population. Evidence of bird catchers in the park indicated that poaching was the main cause. 


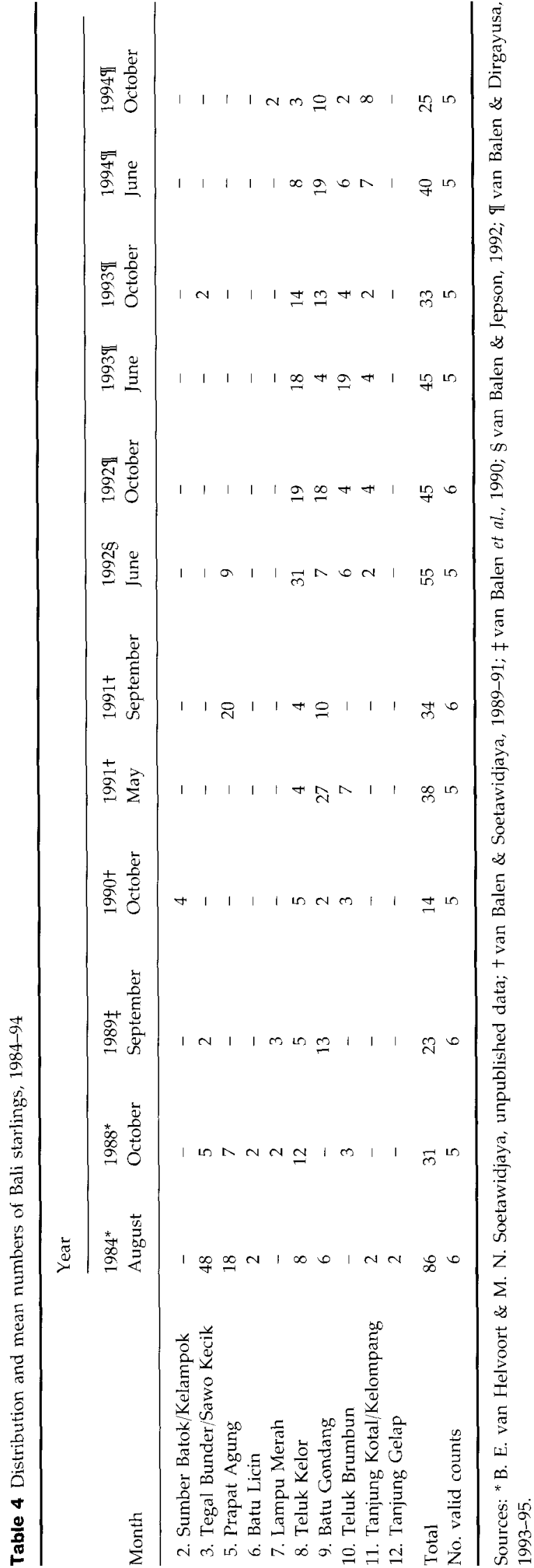

1994 to date: post-Bali Starling Project

In 1994, the BSP was continued by the Bali Barat National Park (BBNP) management as sole executors of the field programme. The dwindling population was monitored closely although the censuses in 1994-95 and 1995-96 were limited to one a year (Suryawan, 1996; PHPA/BirdLife International-IP, 1997). In 1998, six birds were released on two separate occasions (I. Z. Mutaqin \& Samedi, pers. comm., 1998).

\section{Causes of decline}

\section{Habitat conversion}

Most of the former habitat of the Bali starling has been converted into coconut and kapok plantations and human settlements. Dry hill and lowland forest shrunk from an original area of 3550 to $600 \mathrm{sq} \mathrm{km}$ (MacKinnon et al., 1982). Agricultural lands and a village form enclaves within BBNP and it is estimated that about one-third of the c. 10,000 ha of suitable Bali starling habitat in the park has been converted into settlements and plantations (Wind, 1991). Development projects for tourism and the improvement of Bali's infrastructure pose a threat to BBNP's already affected integrity. Outside the national park, the areas inhabited by people along the north and south coast of west Bali had Bali starlings until as recently as the mid-1980s. Development of these areas is, however, proceeding very rapidly and most of it may already be unsuitable for the birds.

Early observations of the species's erratic occurrence suggest seasonal movements. Von Plessen (1926) observed Bali starlings in the mountains between May and July, coinciding with the end of the breeding season, before the birds normally disperse from their breeding grounds. This may suggest the occurrence of birds breeding in the hills, as is supported by several

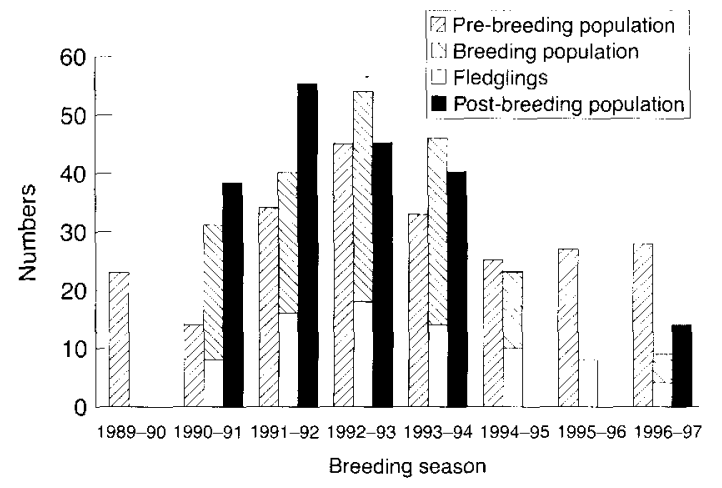

Fig. 2 Numbers of wild birds and fledglings in 1989-97. In 1989-90, 1994-95 and 1995-96 no spring censuses were conducted (after PHPA/BirdLife International-IP, 1997). 


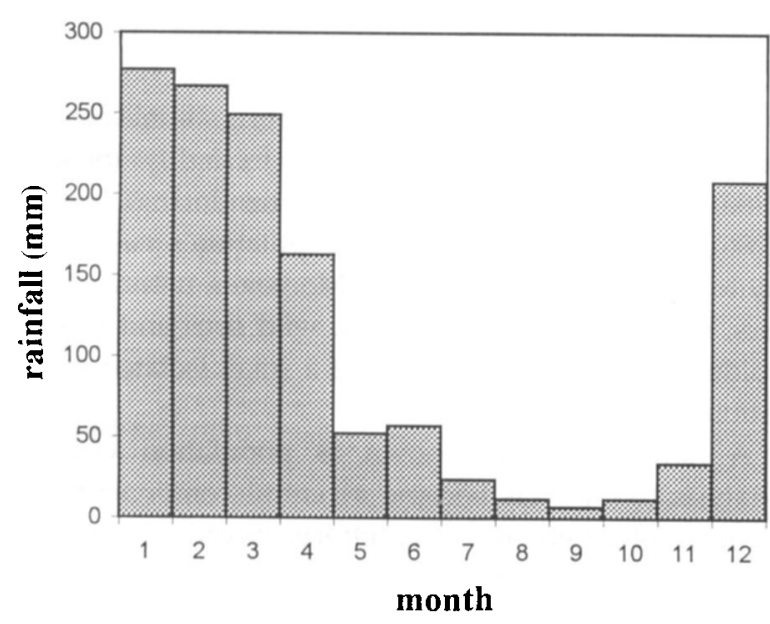

Fig. 3 Average rainfall in north-west Bali (data taken from the Gerokgak Weather Station [after Sandy, 1987]).

nesting pairs of Bali starlings found far inland in foothills north and east of Negara until the mid-1980s (M. W. Adi Putra, unpublished data). Especially towards the end of the dry season, the birds seemed to concentrate in coastal areas, where they had been absent during the wet season (van der Paardt, 1926; von Plessen, 1926). Since then, most of the Bali starling's former habitat has been irreversibly lost to agriculture. This raises the question whether and to what extent the present habitat fragmentation has disrupted the movements between nesting grounds and 'wintering' quarters. It may be necessary to restore habitat ranging from the coastal area to the interior hills, and take this into account in reforestation projects that are planned for Bali. A large part of the areas mentioned above has the status of Protection Forest and has been proposed as an extension of c. 58,000 ha to the national park (MacKinnon et al., 1982). At present, the unclear legal status has resulted in weak protection and general deterioration of the habitat because of human activities.

\section{Illegal captures}

The losses resulting from capture have been severe during the past three decades. Even in the early $1970 \mathrm{~s}$ trading took place on a large scale despite national and international bans. At present, capture is mainly to meet the demand for wild-caught birds within Indonesia. Capturing the wild starlings was traditionally accomplished using birdlime and decoys. Birds were also taken from their nest holes, usually at night. However, more recently mist-nets are being used and the poachers are reportedly well equipped with telescopes and walkie-talkies. Poachers are known to come from the enclave village and mainland Java. Prices of up to
\$US130 for a live bird in 1982 were reported (Ash, 1984 ), and nowadays prices of $\$$ US2000 or more are being paid for the birds on the black market (PHPA/ BirdLife International-IP, 1997). Prices such as these are strong incentives to catch Bali starlings in the wild and make stopping the illegal capture and trade extremely difficult.

The importance of effective protection of the park was demonstrated by the increase of Bali starling numbers as the consequence of a temporary new resurgence of protection and management of Bali Barat in the late 1980s. A second increase in 1991-92 was also the result of a temporary relief from poaching during the period and favourable weather conditions. On the other hand, the zero growth of the population during the otherwise successful breeding seasons of 1992-93 and 1993-94 was the result of largely uncontrolled poaching.

\section{Factors limiting recovery}

\section{Climate}

The rainy season in the north-west part of Bali lasts from December to April, and the dry season from June to October (Sandy, 1987). Shifts by several months are known, e.g. in 1991 and 1993, when the rainy season extended until June/July. Figure 3 shows the rainfall pattern of this part of Bali. Bali starlings breed only during the wet season. The onset of the rains triggers the development of young leaf sprouts and foliageconsuming caterpillars, items that form the main diet of the nestlings during the first weeks (Cahyadin, 1992).

A breeding cycle can be completed in 57 days (van Helvoort et al., 1985). This means that in a wet season of 6-8 months three broods can be raised, but fewer in shorter rainy seasons. While poaching and habitat destruction have been the major cause of the Bali starling's decline in the wild, the climatic unpredictability of the region presents an extra risk factor that has to be taken into account. The long droughts associated with El Niño Southern Oscillations (ENSO) are known to have an especially deleterious impact on the populations of both seabirds and land birds (Schreiber, 1994). Indeed, the ENSO of 1982-83 and that of 1986-87 coincided with a 50 per cent collapse in numbers of wild Bali starlings. Prolonged ENSO-influenced periods of drought were also prevalent during the years 1989 through 1990, when Bali starling numbers dropped almost to zero. In these years, hardly any breeding took place and only two fledglings were observed in the first quarter of 1989 (van Balen et al., 1990).

Day and night temperatures differ to the extent that dew formation is substantial. It is believed that during the dry season the Bali starlings in the driest areas 
largely depend on this when no other water resources are available (van Helvoort, 1990). Circumstantial evidence shows that the starlings sometimes take brackish seawater in the mangroves along the coast (I M. Suta Adi, pers. comm.). Distribution of Bali starlings in the dry season is believed to be influenced by the distribution of available water sources, and attraction to waterholes makes them vulnerable to capture.

\section{Nest hole availability}

As a result of a long history of timber collection and local forest fires, there is a limited number of large trees offering suitable nest sites in peninsular Prapat Agung. Therefore, in 1984-86, 96 nest boxes and excavated logs were installed to offset the presumed shortage of natural nesting sites in the park (van Helvoort et al., 1986). However, only black-winged starlings Sturnus melanopterus, geckos Gecko sp., ants and wild bees were found to use them (van Balen et al., 1990). Further provision of artificial nests has been discontinued until a fuller understanding of the Bali starling nest hole selection process is established. Moreover, numbers of wild starlings are very low now, and nest hole availability will become a limiting factor only when the population recovers substantially.

\section{Inter-specific competition}

The black-winged starling, endemic to Java and Bali and believed to be closely related to the Bali starling, is considered a possible competitor for food resources and nest holes (Sieber, 1978; Hartojo \& Suwelo, 1987). Aggressive behaviour between the two species was observed in the breeding season (Natawiria, 1975), but Bali starlings chased away the black-winged starlings from the former species's breeding territory (Y. Cahyadin, pers. comm., 1991). The black-winged starling is a typical bird of open woodlands and was reported as being very scarce in west Bali in times when forest cover was still extensive and the Bali starlings numerous (von Plessen, 1926). Both species met mainly towards the end of the dry season when mixed flocks were reported foraging on the berries of the Lantana camara shrubs (van der Paardt, 1926; Natawiria, 1975). It has been suggested that because of the recent disappearance or increasing scarcity of certain preferred local fruit trees, and the serious disruption of the closed forest habitat, the more arboreal Bali starling is being crowded out by the black-winged starling in the changed environment (Sontag, 1991, 1992). Ironically, the black-winged starling has itself become scarce in the area as a result of excessive illegal capture for the bird trade, and competition has become irrelevant.

\section{Small population size}

In a very small population inbreeding is inescapable and, because it generally affects fecundity (Senner, 1980) and fitness/adaptability (Allendorf \& Leary, 1986), it frequently increases a population's vulnerability to a changing environment. Moreover, natural disasters, such as extended drought, wild fires and disease epidemics could easily wipe out a small isolated population in one stroke.

A new technique, known as population viability analysis (PVA), has become a central component of a number of recent recovery efforts (Scott et al., 1994). While numbers in the wild were down below 20, calculations at the 1990 Bali Starling PVA Workshop suggested a 100 per cent probability of extinction within a year if no action was taken. The (partly) successful release of captive-bred birds (van Balen \& Gepak, 1994) in April 1990, increased protection of the park, and favourable climatic conditions resulted in a temporary recovery in the following 2 years.

An effective population size has been suggested of not less than 50 in the short term, and 500 in the long term, below which numbers inbreeding would become unacceptably high (Franklin, 1980). An effective population size of 500 birds would require a roughly estimated population of 1000 birds, assuming 50 per cent of the birds are contributing to the breeding pool (Seal, 1990). This number, if distributed over several wild subpopulations in secure areas on Bali, is believed to be sufficient to ensure the Bali starling's viability. Natural habitat has become scarce and reforestation as well as effective forest protection throughout its range is needed to provide enough area to support this number (Wind, 1991). There are also proposals to establish feral populations of Bali starlings in suitable tourist areas elsewhere on Bali (P. Jepson, pers. comm.).

\section{Genetic erosion}

van der Paardt (1926) reported that Bali starlings 'keep shunning people; as soon as village huts appear, the number of birds decline; they are noticeably pushed back by Man'. This is in contrast with more recent accounts of birds breeding in coconut groves adjacent to villages (van Helvoort et al., 1985). It may indicate that the Bali starling was adapting to human presence before poaching pushed it back to its present refuge. Adaptive abilities seen in urbanizing forest birds in Papua New Guinea (Diamond, 1986), or the blackbird Turdus merula in European cities, may be genetically determined (Gehlbach, 1988). Captive stock in the USA and Europe originates largely from birds imported in the early 1970s, when Bali starlings were still relatively 
abundant. Within easy reach of villages and human settlements, they were more susceptible to poaching. Is it possible that more Bali starlings with genetically determined enhanced adaptability were captured from the wild in the early 1970s? And that, in the wild, a depauperate population remained lacking this adaptability and doomed to being confined to a still shrinking habitat patch?

\section{Skewed sex ratio}

Poachers often obtain their birds at night during the breeding season, when females are in the nest holes, and males stay on guard in a nearby tree, safe from poachers (Sieber, 1983; I. Z. Mutaqin, pers. comm.). Indeed, a higher proportion of female than male birds is known to have been exported to the USA in the 1960s (R. E. Seibels, pers. comm.). The resulting skewed sex ratio in the wild may be indicated by field observations of three released, captive-bred females paired to wild males (M. N. Soetawidjaya, pers. comm., 1990; Cahyadin, 1992; I. Z. Mutaqin, pers. comm., 1998), whereas no reverse cases are known. Moreover, breeding activity had ceased almost entirely in the 5-6 years prior to the 1990 releases (B. E. van Helvoort, pers. comm.).

The negative impact of sex-skewed capture in small populations is clear. Franklin (1980) pointed out that an unequal number of sexes would give a smaller effective population and thus increased genetic drift. This then causes inbreeding depression, random change in phenotypes and a decrease in genetic variance.

\section{Weak law enforcement}

Protecting the Bali starling from illegal trade seems straightforward and simple. At the 'source' end of the trade chain the birds are found in a very small area. At the 'sink' end the situation is far less surveyable, but huge penalties exist (in theory) for possessing protected wildlife (PHPA/BirdLife International-IP, 1997), and these should effectively discourage people from capturing, trading and keeping illegal birds. Reality, however, is different. Rich and powerful people can afford to keep Bali starlings without being punished. In the early 1990s, the Indonesian Department of Nature Conservation was charged with a programme aimed at getting hold of captive birds for the breeding and release programme by giving amnesty to illegal keepers of Bali starlings. Implementation was seriously impeded and made ineffectual by a display of power. At the source end the problems are no less complicated. Lack of law enforcement finds its roots in the absence of an effective bonus system for park wardens. Moreover, although occasionally illegal bird catchers have been caught and punished, to date no single illegal keeper has ever been punished. Morale of the park wardens is understandably low. Failure to address this problem has caused the creation of a perverse incentive, and keeping the population low has actually become advantageous. For park guards it means that their jobs are guaranteed and for the bird catchers it means that birds fetch higher prices in the illegal trade.

\section{Future of the Bali starling}

Habitat degradation and excessive capture have brought the Bali starling to the verge of extinction. The hazardous effects of a small population, the intricacy of the law enforcement system and harsh local climatic conditions have so far prevented the Bali starling from emerging from this precarious situation. BirdLife International was involved in the Bali starling conservation programme from 1984 through 1994 in an attempt to strengthen the management of the Bali Barat National Park - the key objective of later phases in its field programme. This, and major achievements in captiverelease techniques (van Balen \& Gepak, 1994; Collins et al., 1998) have not yet resulted in a continued recovery of the wild population of Bali starlings. The main problem has been associated with security in the park. However, topics such as field warden discipline, the arresting and prosecution of poachers and traders, and the gazetting of conservation areas are all outside the sphere of responsibility of international agencies. It is encouraging, therefore, that a Species Recovery Plan has been prepared and adopted in close co-operation with all implementing parties in Indonesia (PHPA/ BirdLife International-IP, 1997). Providing the guidelines for continuation of the conservation programme, this document addresses all aspects of Bali starling conservation: protection in the wild, extension programmes, habitat restoration and law enforcement.

\section{Acknowledgements}

The Bali Starling Project was directed by the PHPA (Ministry of Forestry), BirdLife International, and the American Zoo and Aquarium Association (AZA, formerly AAZPA). Sponsors were the Art Ortenberg/Liz Clairborne Foundation, the Jersey Wildlife Preservation Trust, and the Swedish Ornithological Society. Paul Jepson, Paul Loth, Bob Siebels and an anonymous reviewer gave valuable comments on drafts of the paper. 


\section{References}

Alikodra, H., Sutahardja, H.S., Budi, A.S., Tarumingkeng, R., Suratmo, F.G. \& Basjarudin, H. (1978) Plan for the management and development of Bali Barat Wildlife Reserve. PPA, Bogor [in Indonesian].

Allendorf, F.W. \& Leary, R.F. (1986) Heterozygosity and fitness in natural populations of animals. In Conservation Biology (ed. M. E. Soulé), pp. 57-76. Sinauer, Sunderland, MA.

Ash, J.S. (1984) Bird observations on Bali. Bulletin of the British Ornithologists' Club, 104, 24-35.

Backer, C.A. \& Bakhuizen van den Brink, R.C. (1965) Flora of Java (Spermatophytes Only), vol. II. Noordhoff, Groningen, the Netherlands.

van Balen, B. (1995a) Bibliography of the Bali starling Leucopsar rothschildi 1912-1994. Technical Memorandum 6. PHPA/BirdLife International-Indonesia Programme, Bogor.

van Balen, B. (1995b) Methodology for Population Census of the Bali Starling Leucopsar rothschildi in the Bali Barat National Park. Technical Memorandum 7. PHPA/BirdLife International-Indonesia Programme, Bogor.

van Balen, B. \& Dirgayusa, I W.A. (1993-95) Bali Starling Project activity report. September 1992-February 1995.

PHPA, BirdLife International, Bali Barat NP and AAZPA, Bogor and Gilimanuk [in four parts].

van Balen, S. \& Gepak, V.H. (1994) Captive breeding and the conservation programme of the Bali starling Leucopsar rothschildi. In Creative Conservation (eds G. Mace, P. Olney and A. Feistner), pp. 420-430. Chapman and Hall, London.

van Balen, B. \& Jepson, P. (1992) Bali Starling Project activity report. January-August 1992. PHPA, ICBP, Bali Barat NP and AAZPA, Bogor and Gilimanuk.

van Balen, S. \& Soetawidjaya, M.N. (1989-91) Bali Starling Project progress report. Among Satwa Mrih Lestari, Buletin PKBSI, 28, 13-14; 39, 8-9; 42, 24-25; 45, 27-29; 47, 22-23; 50, 19-20

van Balen, B., van Helvoort, B.E. \& Soetawidjaya, M.N. (1990) Bali Starling Project III progress report July 1987-September 1990. ICBP, PHPA, AAZPA and JWPT, Bogor and Gilimanuk.

van Bemmel, A.C.V. (1974) Balispreeuwen. Artis, 20, $134-137$.

Cahyadin, Y. (1992) Several ecological aspects of the Bali starling Leucopsar rothschildi Stresemann 1912 in the breeding season at Teluk Kelor, Bali Barat National Park. Student report, Padjadjaran University, Bandung, Indonesia [in Indonesian].

Collar, N.J., Crosby, M.J. \& Stattersfield, A.J. (1994) Birds to Watch 2. The World List of Threatened Birds BirdLife Conservation Series No. 4. BirdLife International, Cambridge, UK.

Collins, M.S., Smith, T.B., Seibels, R.E. \& Adi Putra, I M.W (1998) Approaches to the reintroduction of the Bali mynah. Zoo Biology, 17, 267-284.

de Iongh, H.H, Komara, A., Moeliono, M., Pratjihno, P.S., Spliethof, P.C. \& Soenarja, I.S. (1979) Report on a survey of the Bali tiger (Panthera tigris balica Schwarz 1912) and Bali mynah (Leucopsar rothschildi Stresemann 1912). March-April 1979. Van Tienhovens Foundation, Amsterdam [in Indonesian]. de Iongh, H.H, Komara, A., Moeliono, M., Soemarto, P., Soebrata, S., Spliethof, P.C. \& Soenarja, I.S. (1982) A survey of the Bali mynah Leucopsar rothschildi Stresemann 1912. Biological Conservation, 23, 291-295.

Diamond, J.M. (1986) Rapid evolution of urban birds. Nature, $324,107-108$

Ezra, A. (1931) Successful breeding in Galeopsar salvadori and Leucopsar rothschildi. Avicultural Magazine, 9, 305-307.

Franklin, I.R. (1980) Evolutionary change in small populations. In Conservation Biology, an Evolutionary-Ecological Perspective (eds M. E. Soulé and B. A. Wilcox), pp. 135-149. Sinauer, Sunderland, MA.

Gehlbach, F.R. (1988) Population and environmental features that promote adaptation to urban ecosystems: the case of eastern screech-owls (Otus asio) in Texas. Acta Congressus Internationalis Ornithologici, XIX, 1809-1813.

Harrison, C.J.O. (1968) Rothschild's mynah: an appeal for co-operation. Avicultural Magazine, 74, 19-20.

Hartojo, P. \& Suwelo, I.S. (1987) Conservation efforts for the Bali starling. Media Konservasi, 1(4), 29-39 [in Indonesian].

van Helvoort, B.E. (1990) The Bali starling Leucopsar rothschildi Stresemann 1912; its current status and need for conservation. In Proceedings ASEAN Workshop on Wildlife Research and Management, pp. 115-131. PHPA, Bogor.

van Helvoort, B.E., Soetawidjaya, M.N. \& Hartojo, P. (1985) The Rothschild's Mynah (Leucopsar rothschildi): a Case for Captive or Wild Breeding? ICBP, Cambridge.

van Helvoort, B.E., Soetawidjaya, M.N. \& Hartojo, P. (1986) The Rothschild's Mynah (Leucopsar rothschildi): a Case for Captive or Wild Breeding? ICBP, Cambridge.

Jepson, P. (1997) Birding Indonesia. A Bird-watcher's Guide to the World's Largest Archipelago. Periplus, Singapore.

Junge, G.C.A. (1953) Ornithological research in the Dutch Indies. Ardea, 41, 301-334 [in Dutch].

King, W.B. (1974) Aspects of international trade in Indonesian birds. International Zoo Yearbook, 14, 56-61.

MacKinnon, J., Smiet, F. \& Artha, M.B. (1982) National conservation plan for Indonesia. Vol. III. Jaza and Bali. Field Report INS/78/061. UNDP/FAO National Parks Development Project, Bogor.

Morrison, A. (1981) A note on the Javanese aviculture. Avicultural Magazine, 86, 108-110.

Natawiria, D. (1975) Second survey of the Bali starling (Leucopsar rothschildi Stres.) in Bali Barat Nature Reserve. Report No. 211. Forestry Research Institute, Bogor [in Indonesian].

van der Paardt, Th. (1926) Manoek poetih: Leucopsar rothschildi. De Tropische Natuur, 15, 169-173.

von Plessen, Baron V. (1926) Verbreitung und Lebensweise von Leucopsar rothschildi Stres. Omithologische Monatsberichte, 34, 71-73.

PHPA/BirdLife International-IP (1997) Bali Starling Recovery Plan. PHPA/BirdLife International-Indonesia Programme, Bogor.

Sandy, I M. (1987) Regional Climates of Indonesia. Geography Department, University of Indonesia, Jakarta [in Indonesian].

Schreiber, E.A. (1994) El Niño-Southern Oscillation events may be affecting your field data as they alter weather patterns worldwide. Journal für Ornithologie, 135 (Suppl.), 210. 
Scott, J.M., Temple, S.A., Harlow, D.L. \& Shaffer, M.L. (1994) Restoration and management of endangered species. In Research and Management Techniques for Wildlife and Habitats (ed. T. A. Bookhout), pp. 531-539. The Wildlife Society, Bethesda, MD.

Seal, U.S. (1990) Bali starling Leucopsar rothschildi viability analysis and species survival plan. Bogor: PHPA, ICBP, AAZPA, JWPT, CBSG, SSC and IUCN. Workshop Report.

Seibels, R.E. \& Bell, K.J. (1993) The Bali mynah. The American Association of Zoological Parks and Aquaria's species survival plan. Avicultural Magazine, 99, 207-212.

Senner, J.W. (1980) Inbreeding depression and the survival of zoo populations. In Conservation Biology, An Evolutionary-Ecological Perspective (eds M. E. Soulé and B. A. Wilcox), pp. 209-224. Sinauer, Sunderland, MA.

Sieber, J. (1978) Freilandbeobachtungen und Versuche einer Bestandaufnahme des Bali-Stars Leucopsar rothschildi. Journal für Ornithologie, 119, 102-106.

Sieber, J. (1983) Nestbau, Brut und Jungenaufzucht beim Balistar (Leucopsar rothschildi). Zoologischer Garten N.F., Jena, 53, 281-289.

Smiet, A.C. (1992) Forest ecology on Java: human impact and vegetation of montane forest. Journal Tropical Ecology, $8,129-152$.

Sontag, W.A. (1991) Zur Habitatsnutzung beim Balistar (Leucopsar rothschildi): Vergleich mit einer nahverwandten Referenzart. Secoögel, Zeitschrift Verein Jordsand, 12 (Suppl.), 111-113.

Sontag, W.A. (1992) On habitat utilization in various south Asian starlings (Sturnidae). Mitteilungen aus dem zoologischen Museum in Berlin, 68 (Suppl.: Ann. Orn. 16), $115-123$.

Spilsbury, D.T. (1970) Rothschild's mynah (Leucopsar rothschildi). Register and report on 1969 census. Avicultural Magazine, 76, 115-129.

Stresemann, E. (1912) Description of a new genus and new species of bird from the Dutch East India Islands. Bulletin of the British Ornithologists' Club, 31, 4-6.

Stresemann, E. (1913) Die Vögel von Bali, aus den Zoologischen Ergebnissen der II. Freiburger Molukken-Expedition. Novitates Zoologicae, 20, 325-387.

Sungkawa, W., Natawiria, D., Prawira, R.S.A. \& Kurnia, F. (1974) Observations on the Bali starling (Leucopsar rothschildi) in Bali Barat Nature Reserve. Report No. 195. Forestry Research Institute, Bogor [in Indonesian].

Suryawan, W. (1996) Inventory report on the Bali starling Leucopsar rothschildi in Bali Barat National Park. Internal Report, Forestry Department and Bali Barat National Park, Cekik, Bali [in Indonesian].

Suwelo, I.S. (1976) Study on the habitat and population of the Bali Barat nature reserve. PPA and Universitas Indonesia, Bogor and Jakarta [in Indonesian].
Walker, S.H., Eavis, B.W., Harris, J.C, Laurence, J.F., Moffatt, D.J. \& Robertson, C.A. (1980) Development of the water resources of Bali: a master plan. Land Resource Report 31. Ministry of Overseas Development, Surbiton.

West, C.C. \& Pugh, P.B. (1986) Breeding and behaviour of Rothschild's mynah. Dodo, 22, 84-97.

Whitmore, T.C. (1990) Tropical Rain Forests of the Far East. Clarendon Press, Oxford.

Whitten, T., Soeriaatmadja, R.E. \& Afiff, S.A. (1996) The ecology of Java and Bali. In The Ecology of Indonesia Series 2. Periplus, Singapore.

Wind, J. (1991) Bali Barat National Park Zoning and Restoration Plan. PHPA and DHV Consultants Netherlands, Bogor and Amersfoort.

\section{Biographical sketches}

Sebastianus (Bas) van Balen graduated in 1982 in biology from the University of Utrecht. In 1999, he obtained his $\mathrm{PhD}$ degree at the Wageningen University with a thesis on Javan forest birds and habitat fragmentation. Since 1980, he has been conducting bird surveys throughout Indonesia for the Indonesian Ministry of Forestry and the Indonesian programmes of BirdLife International, Center for International Forest Research, World Wide Fund for Nature, Wetlands International, Wildlife Conservation Society and various other organizations. From 1989 until 1994, he worked for BirdLife International as field director for the Bali Starling project in co-operation with the American Zoo Association.

I Wayan Agus Dirgayusa graduated in 1990 in biology from the Padjadjaran University, Bandung (Indonesia). He was field officer of the Bali Starling Project for BirdLife International from 1993 until 1995. He is currently working as a freelance consultant on various conservation projects throughout Indonesia.

I Made Wedana graduated in 1993 in biology from the Padjadjaran University in Bandung (Indonesia). Since 1991, he has been involved in numerous conservation projects on threatened (bird and primate) species in Java, Sumatra and Kalimantan. From 1993 to 1998 , he was field officer in the Bali Starling captive breeding and re-introduction programme for the American Zoo Association. Currently he is programme co-ordinator for a local nature conservation agency, named KONUS (The Archipelago Nature Conservation Society). 